\title{
National safeguard clauses (Art. 23/ RL 2001/18) - The role of EFSA \& National Biosafety Committees
}

\author{
D. Bartsch \\ Federal Office for Consumer Protection and Food Safety (BVL), Berlin, Germany \\ Correspondence to: Prof. Dr. Detlef Bartsch, Federal Office for Consumer Protection and Food Safety (BVL), \\ Mauerstr. 39-42, D-10117 Berlin, Germany, E-mail: detlef.bartsch@bvl.bund.de
}

Since 2003, EFSA has been requested by the European Commission, under Article 29(1) and in accordance with Article 22(2) and 22(5)(c) of Regulation (EC) No 178/2002, to assess the information submitted by Member States (MS) concerning the invoke of Article 16 of Directive (EEC) 90/220 or Article 23 of Directive (EC) No 2001/18 ('safeguard clauses'). The MS were Luxemburg for Bt176 maize; Germany for Bt176 and temporarily (in 2007) MON810 maize; Austria for Bt176, MON810 and T25 maize; France for Ms1xRf1, and Topas 19/2 oilseed rape, and MON810 maize; Hungary for MON810 maize, and Greece for Topas 19/2 oilseed rape and MON810 maize. The level of scientific information provided in the various safeguard clauses is very heterogeneous. In all cases the GMO Panel concluded, that, with respect to the specific questions raised, and on the basis of current scientific knowledge, there is no reason to believe that the continued placing on the market of Bt176, T25 \& MON810 maize, and Ms1xRf1 \& Topas 19/2 oilseed rape is likely to cause any adverse effects for human and animal health or the environment under the conditions of their respecttive consents (EFSA, 2004a,b, 2005, 2006a,b, 2008a,b). There is a discussion whether EFSA should request the opinion of the established Scientific Biosafety Committee of the applying EU Member State in order to clarify the scientific basis of future safeguard applications. With one exception (ZKBS, 2007), the author is not aware that such a national Biosafety Committee has published a scientific statement in relation to their specific Member State action. Another point of discussion might be on the novelty or additional scientific knowledge to base the safeguard clause on. In the safeguard clause issued in 2006 by Austria on GT73 oilseed rape for import, the argumentation had already been assessed (and dismissed) by the MS Authority (e. g. The Netherlands) under Directive 2001/18/EC who initially issued the consent. Despite that fact, in 2008, the same document was sent to EFSA again to justify a safeguard clause. A formal standardisation of the information required in support of a safeguard clause (e. g. novelty, additional scientific information, opinion of the national Biosafety Committee etc.) would be a way forward to streamline the regulatory requirement that the Member State shall immediately supply its review of the environmental risk assessment.

\section{Literature}

EFSA (2004a) Opinion of the GMO Panel on a request from the Commission related to the Austrian invoke of Article 23 of Directive 2001/18/EC. EFSA J 78:1-13.

EFSA (2004b) Opinion of the GMO Panel on a request from the Commission related to the Greek invoke of Article 23 of Directive 2001/18/EC. EFSA J 78:1-8.

EFSA (2005) Opinion of the GMO Panel on a request from the Commission related to the safeguard clause invoked by Hungary according to Article 23 of Directive 2001/18/EC. EFSA J 228:1-14.

EFSA (2006a) Opinion of the GMO Panel on a request from the Commission related to genetically modified crops (Bt176 maize, MON810 maize, T25 maize, Topas 19/2 oilseed rape and Ms1xRf1 oilseed rape) subject to safeguard clauses invoked according to Article 16 of Directive 90/220/EEC. EFSA J 338:-15.

EFSA (2006b) Opinion of the GMO Panel on a request from the Commission related to the safeguard clause invoked by Greece according to Article 23 of Directive 2001/18/EC and to Article 18 of Directive 2002/53/EC. EFSA J 411:1-26.

EFSA (2008a) Opinion of the GMO Panel on a request from the European Commission related to the safeguard clause invoked by Greece on maize MON810 according to Article 23 of Directive 2001/18/EC. EFSA J 757:1-12.

EFSA (2008b) Opinion of the GMO Panel on a request from the European Commission related to the safeguard clause invoked by Hungary on maize MON810 according to Article 23 of Directive 2001/18/EC. EFSA J 756:1-18.

ZKBS (2007) Opinion of the German Biosafety Commission (ZKBS) on the temporary stop of authorization of MON810 maize [Stellungnahme der ZKBS zum Bescheid des BVL (Teilweises Ruhen der Inverkehrbringens-Genehmigung des gentechnisch veränderten Maises MON810) vom 27. April 2007]

http://www.bvl.bund.de/cln_007/nn_1208608/DE/06_Gentechnik/ 093_ZKBS/01_Allg_Stellungnahmen/04_pflanzen/ Mon810.html 